\title{
Neurologische morbiditeit bij COVID-19
}

André Weel

Ellul MA, Benjamin L, Singh B et al. Neurological associations of COVID-19. Rapid review.

Lancet Neurol 2020; 19: 767-83. https://doi.org/10.1016/ S14744422(20)30221-0
Mark Ellul van de Universiteit van Liverpool en negen collega's publiceerden afgelopen zomer een rapid review over de neurologische morbiditeit bij COVID-19. Het artikel is een momentopname aan het eind van de eerste golf van de pandemie. Welke schade kan het coronavirus aanrichten aan het centrale en perifere zenuwstelsel? Het meest bekend zijn het verlies van reuk en smaak, maar er is meer aan de hand. Ellul en collega's verzamelden 29 case reports met in totaal 901 patiënten met neurologische verschijnselen die aan COVID-19 worden toegeschreven. Een rapid review in termen van The Lancet. Het aantal patiënten met neurologische aandoeningen door COVID zal nu, in januari 2021, een veelvoud zijn van die 901 van afgelopen juli.

Bij COVID-19 staan respiratoire symptomen op de voorgrond. Neurologische manifestaties van coronavirusinfectie zijn relatief zeldzaam. Bij SARS (2003) was de fractie patiënten met neurologische symptomen 0,09\% en bij MERS (2012) 0,36\%. Van COVID-19 kunnen we de percentages alleen nog maar schatten. Gelet op de schaal waarop de pandemie zich ontrolt, met momenteel bijna 70 miljoen bevestigde ziektegevallen, mag men aannemen dat er vele tienduizenden COVID-patiënten met neurologische problemen zullen zijn. Een aantal van deze complicaties leidt tot blijvende invaliditeit. De schattingen die de auteurs maken omvatten niet de COVID-gevallen die gepaard gaan met een cerebrovasculair accident. Het acute CVA blijkt juist wél een veelvoorkomende complicatie te zijn. Uit cohortstudies blijkt dat 2 tot $6 \%$ van de patiënten die met COVID-19 in het ziekenhuis worden opgenomen, een CVA krijgt. De auteurs besteden veel aandacht aan de betekenis van casedefinities. Zij onderscheiden niet-specifieke neurologische complicaties die je bij elke ernstige aandoening ziet, van complicaties die aan het virus zijn toe te schrijven, zoals encefalitis, myelitis en het syndroom van GuillainBarré. Stollingsstoornissen die tot een CVA kunnen leiden, met name hypercoagulabiliteit, vallen ook onder die laatste categorie.
Natuurlijk kunnen patiënten met pre-existente neurologische aandoeningen geïnfecteerd raken met het coronavirus. Dit ziet men vooral in ziekenhuizen en verpleeghuizen. Als deze patiënten besmet raken met het coronavirus, is het zaak onderscheid te maken tussen een louter nasofaryngeale infectie en een infectie die ook het zenuwstelsel aantast. Om dat laatste vast te stellen is verder onderzoek nodig, zoals het onderzoeken van de liquor op coronavirus. Tenslotte wijzen de auteurs erop dat patiënten die positief op COVID-19 zijn getest weinig of geen typische klachten van de luchtwegen kunnen hebben, maar wel een neurologisch beeld kunnen ontwikkelen. Dit laatste wordt in toenemende mate gezien, zo blijkt uit de case reports. Men moet dan uitzoeken of de COVID-19-infectie causaal is voor het neurologische beeld, dan wel coïncidenteel. Kortom, er is nog veel werk te doen. De auteurs roepen op om de klinische ervaringen samen te brengen in internationale pools, zoals het COVID-19 Neuro Network. Voor meer informatie zie https://braininfectionsglobal. tghn.org/ Het onderzoekersnetwerk Brain Infections Global levert standaardformulieren om casussen te melden en geeft ook de casedefinities.

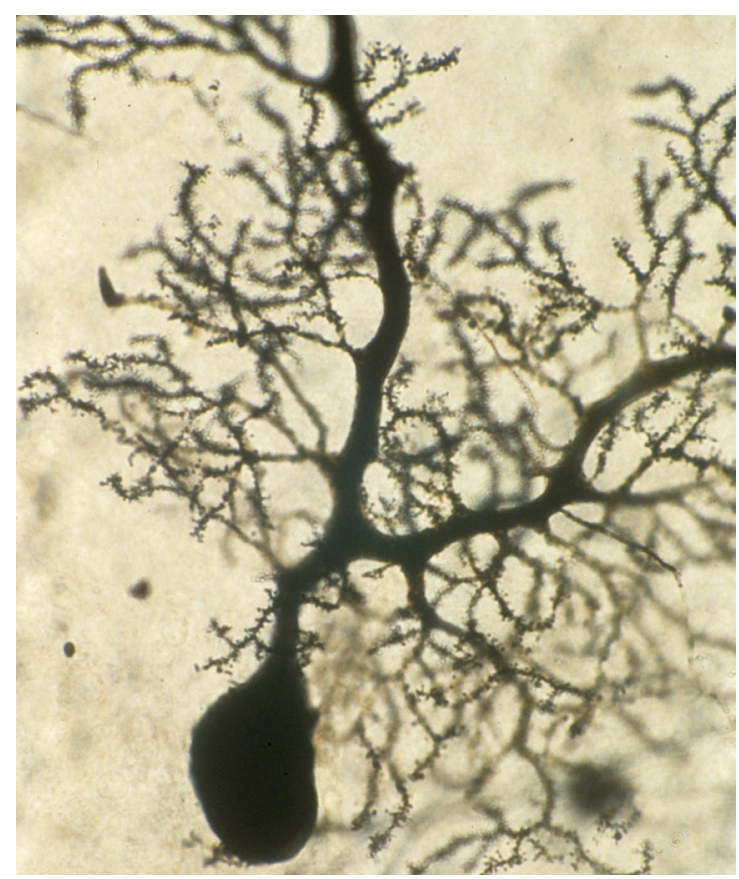

